\title{
KOMUNIKASI DAKWAH KETURUNAN ALAWIYYIN DALAM PENYEBARAN PENDIDIKAN ISLAM DI KOTA PALU
}

\author{
Raisa Alatas \\ Program Studi Ilmu Komunikasi Fakultas Ilmu Sosial dan Ilmu Politik \\ Email: raisaalatas.ra@gmail.com
}

\begin{abstract}
ABSTRAK
Tujuan dari artikel ini adalah mendeskripsikan proses komunikasi dakwah dalam pendidikan Islam beserta pembentukan cara pandang oleh keturunan Alawiyyin di kota Palu-Sulawesi Tengah pada kawasan Sis-Aljufri atau biasa juga dikenal dengan lingkungan Alkhairaat. Habib Idrus Bin Salim Aljufri dikenal kredibilitasnya dan otoritasnya melalui pendekatan yaitu pendidikan Islam dan dakwah. Metode Penelitian yang digunakan dalam artikel ini adalah kualitatif dengan pendekatan studi kasus. Hasil penelitian pada lapangan ditemukan bahwa para keturunan Alawiyyin sebagai komunikator dengan kredibilitas yang telah dilihat oleh khalayaknya mengarah ke sifat positif dengan sebutan sebagai 'orang alim'. Konsep diri ini merupakan suatu identitas, cita-cita, ideologi ataupun paham, dan penilaian diri dari orang lain. Konten-konten syiar dalam berdakwah keturunan Alawiyyin dibentuk dalam model qira'ah, bantuan penerjemah hingga alat peraga. Konsep tiada hari tanpa membaca digunakan dimanapun dan kapanpun oleh keturunan Alawiyyin dalam melakukan proses dakwah. Pada akhir proses terbentuklah tujuan awal masuknya keturunan Alawiyyin yaitu konsep manifestasi budaya yang tercipta dari zaman kedatangan keturunan Alawiyyin (Habib Idrus bin Salim Aljufri) hingga kini dengan tetap berdiri dan beroperasinya pendidikan Islam, Alkhairaat di wilayah Indonesia timur dan berpusat di kota Palu.
\end{abstract}

\section{Kata Kunci: Komunikasi Dakwah; Alawiyyin; Pendidikan Islam; Guru Tua}

\section{Submisission: 26 April 2021}

\section{Pendahuluan}

Proses penyebaran agama Islam di dahului oleh kedatangan bangsa Arab sebagai source (komunikator) dalam penyebaran agama Islam di Indonesia dan suku pribumi bertindak sebagai komunikan dalam penyebaran ini. Penyebaran Islam di Nusantara menurut Ricklef, secara umum ada dua proses yang mungkin telah terjadi, pertama, penduduk pribumi mengalami kontak dengan agama Islam dan kemudian menganutnya. Proses kedua, orang-orang asing Asia (Arab, Cina, India, dll), yang telah memeluk agama Islam tinggal secara tetap di suatu wilayah Indonesia, menikah dengan penduduk asli, dan mengikuti gaya hidup local (Ricklef, 2009). 
Komunikasi dengan mengakses media sosial menjadi teori dan praktek baru yang digunakan oleh masyarakat luas sebagai cara untuk mendapatkan informasi bahkan ilmu pengetahuan baru. Dimana dalam kajian ini dibatasi pada permasalahan agama Islam. Komunikasi akan membentuk sistem sosial dalam organisasi pendidikan, sistem ini akan mempengaruhi bagaimana komunikasi dalam organisasi itu terjadi serta menentukan arah kepada siapa komunikasi itu ada ( Cahyono 2019).

Komunikasi dakwah ialah proses penyampaian informasi atau pesan yang bersumber dari al-qur'an dan hadis dari seseorang atau sekelompok orang kepada seseorang atau sekelompok orang lainya dengan tujuan untuk mengubah sikap, pendapat, atau perilaku orang lain yang lebih baik se- suai ajaran Islam, baik langsung secara lisan, maupun tidak langsung melalui media. Media yang di- gunakan harus mampu mengikuti perkembangan teknologi yang ada, agar mampu diterima dengan baik ( Fitria 2020). Menurut bentuknya, komunikasi dibedakan menjadi dua,verbal dan non verbal. Mengingat luasnya ruang lingkup komunikasi, tulisan ini hanya akan difokuskan pada komunikasi verbal, yakni bentuk komunikasi dakwah efektif yang manggunakan simbol-simbol bermakna dan berlaku umum dalam proses komunikasi verbal yang mengunakan simbol suara saja (Markama 2014).

Keberhasilan dakwah di pengaruhi oleh metode, media yang di gunakan, sebaik apapun penguasaan materi yang dimiliki oleh da'i bukan satu-satunya faktor penentu keberhasilan,kemampuan untuk memilih dan menggunakan metode dakwah yang tepat sesuai dengan kondisi obyektif. Ketepatan dalam memilih metode dan media dakwah akan sangat membantu da ${ }^{e c} \mathrm{i}$ untuk lebih mudah menyampaikan psan-pesan dakwah. Pada dasarnya agar pesan-pesan dakwah bisa tersampaikan dengan mudah pada masyarakat kita harus bisa menyesuaikan apa yang menjadi kebiasaan masyarakat dalam berperilaku, kebudayaan dan sebagainya. pendeknya, apa yang selalu menjadi kebiasaan mereka, disitulah kita bisa menjadikannya sebagai sarana untuk berdakwah ( Yanti 2016).

Dakwah dikembangkan dengan ilmu komunikasi, dan ilmu komunikasi juga mengalami perluasan area dan perkembangan melalui intensitas dakwah, karena itu lah komunikasi dan dakwah saling berhubungan satu sama lain, dan dakwah sangat membutuhkan komunikasi untuk bisa mempengaruhi para mad'u (komunikator). Kegitan komunikasi dakwah tidak akan pernah terlepas dari komunikator dan komunikan yang saling mempengaruhi satu sama lain ( Rahman 2019 ).

Proses yang terjadi antara pertemuan etnis asing dan etnis pribumi merupakan pertemuan yang membutuhkan adaptasi maupun penyesuaian yang dapat meningkatkan hubungan ke tahap yang lebih baik agar menghasilkan efek yang baik diantara kedua belah pihak. Keturunan Alawiyyin tidak serta-merta bisa bergabung dengan masyarakat pribumi. Proses relationship keagamaan beserta pembentukan cara pandang terjadi pada mereka dengan keIslaman kaum Arab dan sifat 
berkelompok yang masih tertanam sampai saat ini juga.

Dalam menyebarkan agama Islam, dengan cara yang bijaksana, menggunakan nasehat-nasehat yang dapat tersentuh hatinya, dan berdiskusi dengan cara yang baik, sehingga pesan dakwah Islam dapat diterima dan dilaksanakan oleh masyarakat pada umumnya. Terdapat berbagai media baru dalam berdakwah menjadi salah satu tren dalam menyebarkan agama islam kepada khalayak luas. Akan tetapi, metode dakwah dilakukan secara konvensional/tradisional masih menjadi pilihan tersendiri sebagian pendakwah. Masih menggunakan metode syiar Islam seperti yang dilakukan oleh wali sembilan, menggunakan pendekatan budaya dalam berdakwah. Sunan Kalijaga dalam berdakwah tidak meninggalkan budaya. Beliau berpendapat, bahwa ketika budaya mulai di tinggalkan maka masyarakat akan takut dan tidak mau untuk mendekat kepada ajaran agama, dakwah harus disesuaikan dengan situasi dan kondisi wilayah tersebut (Wibowo 2015).

Di Palu-Sulawesi Tengah, warga keturunan Arab berada di kawasan SisAljufri atau biasa juga dikenal dengan lingkungan Alkhairaat. Keturunan Arab sendiri lagi terbagi menjadi dua yaitu bangsa masa'ikh dan bangsa sayyid (Alawiyyin). Golongan Sayyid (Alawiyyin) merupakan kelompok yang termasuk kelas tertinggi dalam masyarakat Hadramaut dan kelompok religius yang mengklaim sebagai keturunan langsung Nabi Muhammad SAW, melalui Fatimah Az-Zahra yang menikah dengan Ali bin Abi Thalib dan di karuniai dua anak yakni Hasan dan
Husein sedangkan bangsa masa'ikh dan qaba'il, kelompok ini terdiri dari para intelektual, sarjana, bangsawan dan kepala suku. Pada awalnya masha'ikh (sarjana) memegang kepemimpinan religius, tetapi terpinggirkan oleh kedatangan para sayyid. Meskipun demikian, mereka tetap di hormati karena memiliki kebaikan secara turuntemurun (Ruslan, 2017). Kaum Alawiyyin membuktikan hal-hal seperti bagaimana peran source (komunikator) menyampaikan pesan kepada komunikan dan kemudian membawa kebudayaan minoritas ini menjadi dominan melalui dialog ataupun sosialisasi yang dilakukannya bersama suku asli setempat.

Habib Idrus Bin Salim Aljufri merupakan salah satu tokoh warga keturunan Alawiyyin yang penting yang membawa keakraban antara warga keturunan Arab dalam hal ini keturunan Alawiyyin dengan suku asli Kaili sebagai suku asli setempat. Bahkan nama Habib Idrus Bin Salim Aljufri atau Guru Tua digunakan sebagai nama bandara Sulawesi Tengah. Ini menjadikan Kota Palu Provinsi Sulawesi Tengah sebagai satu-satunya provinsi yang mempunyai nama bandara memakai nama warga keturunan Arab/Alawiyyin di dalam kawasan Indonesia yang memiliki keragaman budaya yang kuat. Semua ini tidak serta merta terjadi tanpa ada sebab musabab kredibilitas dari seorang komunikator.

Walikota Palu dalam sambutan pada acara haul Habib Sayyid Idrus mengatakan bahwa Palu tidak akan seperti ini, jika Habib Idris tidak datang ke Palu (Mastura, 2015). Ini membuktikan pada saat itu rakyat Palu 
yang mempunyai berbagai macam kepercayaan dan agama tidak mempunyai tempat bertumpu dalam keIslaman mereka walaupun sebelum kedatangan Habib Idrus, Datok Karama terlebih dahulu datang ke Palu untuk melakukan dakwah tanpa adanya wadah untuk mereka mengemban ilmu keIslaman.

Semua kepercayaan-kepercayaan itu kemudian akhirnya berangsur-angsur hilang karena pendidikan dan dakwah Sayyid Idrus melalui Alkhairaat. Sayyid Idrus datang ke Palu dengan mendirikan pendidikan Islam Alkhairaat ditengah masih banyaknya masyarakat yang menganut paham bercampur animisme. Dari beberapa penelitian terdahulu mengenai proses pendekatan keturunan Alawiyyin kepada pribumi seperti dalam penelitian yang dilakukan pada Universiti kebangsaan malaysia, pendekatan yang dilakukan memakai pendekatan ekonomi dan agama, namun yang kemudian terjadi di kota Palu yaitu pendekatan pendidikan dan juga dakwah berlaku di sana (Rozali, 2012).

Habib Idrus kemudian tidak sendiri dalam penyebaran pendidikan Islam di kota Palu. Guru Tua begitu sebutan akrab warga kota Palu kepada Habib Idrus bersama anak, cucu, dan murid-muridnya berusaha memasukkan ilmu-ilmu Islam ditengah keadaan kota Palu marak dengan organisasi yang menjurus pada paham animisme, Habib Idrus datang dengan pengetahuan keIslaman yang baik dari Hadramaut untuk membawa angin segar di Palu. Habib Idrus Bin Salim Aljufri dikenal kredibilitasnya dan otoritasnya dari segi kaum Alawiyyin di Sulawesi Tengah bahkan Indonesia Timur. Khalayak atau komunikan disini tentu lebih cenderung memperhatikan dan mengingat pesan dari komunikator yang mereka percaya sebagai orang yang memiliki pengalaman dan pengetahuan yang luas dalam bidang yang akan mereka sebarkan tersebut.

Pendekatan melalui pendidikan dan dakwah digunakan keturunan Alawiyyin kota Palu untuk mencapai tujuan bersama bersama suku asli dalam meningkatkan agama dan juga pendidikan itu sendiri. Pendekatan melalui pendidikan sebagai proses yang menekankan pembentukan karakter manusia sosial dapat bisa mengatasi sebuah konflik etnis dan permasalahan silang budaya. Bidang pendidikan merupakan salah satu cara yang digunakan oleh keturunan Alawiyyin di kota Palu untuk bisa membangun komunikasi yang baik dengan masyarakat suku asli Kaili. Peran lembaga pendidikan yang dibangun oleh warga keturunan Alawiyyin Palu menjadi salah satu poin penting bagaimana polapola komunikasi mereka terjadi dalam proses hubungan keagamaan keagamaan antar etnis yang sedang terjadi dari dahulu hingga sekarang.

Pesantren Alkhairaat (PA) Palu adalah sebuah pesantren yang sangat terkenal khususnya di Indonesia Timur. Pesantren yang merupakan efek dari hubungan antar kedua budaya ini telah memiliki ratusan cabang di berbagai provinsi, kota dan kabupaten di Indonesia Timur. Saat ini bahkan sudah memiliki cabang di Jawa. Dalam segi dinamisnya pergerakan dan kemajuan Pesantren Alkhairaat (PA), ia adalah Pondok Gontornya Indonesia Timur yang tiap tahunnya akan dimasuki oleh 
ratusan murid bukan hanya dengan latar belakang keturunan Alawiyyin, justru etnis Kaili yang lebih banyak menimba ilmu ditempat ini (Konsultasi Syariah Islam Al-Khoirot, 2012).

Tujuan utama berdirinya perguruan Islam Alkhairaat pada saat itu adalah dengan tujuan mulia yakni untuk mencerdaskan umat dengan cara memberikan pendidikan dan ilmu pengetahuan sehingga terbebas dari kebodohan dan kemelaratan. Alkhairaat merupakan lembaga swasta di masa sekarang yang kemudian menjadi mitra pemerintah namun tetap bergerak di bidang pendidikan dan dakwah (Kambay, 1991).

\section{Metode Penelitian}

Sesuai dengan rumusan permasalahan dan tujuan yang ingin dicapai maka penelitian ini merupakan penelitian kualitatif. Adapun metode dan pendekatan yang akan dipakai dalam penelitian ini adalah studi kasus. Pokok permasalahan yang diajukan dalam penelitian ini menyangkut komunikasi dakwah keturunan Alawiyyin dalam penyebaran pendidikan Islam di kota Palu. Studi ini akan mengarah pada pendeskripsian masalah secara rinci dan mendalam mengenai potret kondisi tentang apa yang sebenarnya terjadi menurut apa adanya dilapangan.

Penelitian studi kasus adalah pendekatan kualitatif yang meneliti kehidupan nyata, kasus atau berbagai kasus melalui pengumpulan data yang detail dan mendalam yang melibatkan berbagai sumber informasi atau sumber informasi majemuk seperti pengamatan, wawancara, bahan audiovisual dan dokumen dari berbagai laporan dan kemudian melaporkan deskripsi kasus dan tema kasus (Creswell, 2015; Yin, 2013). Terkait dengan penelitian di atas, studi kasus yang dilakukan dalam penelitian ini mengambil lokasi di Alkhairaat kota Palu Sulawesi Tengah. Untuk mendukung data yang ada, peneliti juga melakukan observasi langsung ke yayasan Alkhairaat.

Untuk sampling yang digunakan, peneliti menggunakan purposive sampling guna memperoleh kedalaman atas data yang diperoleh. Dalam proses penelitian ini seleksi terhadap sumber data primer (informan) dilakukan bersamaan dengan proses pengumpulan data yaitu dengan teknik snowball sampling (A. Muri Yusuf, 2014; Arikunto, 2010). Hal ini dilakukan karena peneliti belum memiliki data pasti dan lengkap mengenai jumlah dan karakteristik sumber data di lokasi penelitian. Kecukupan jumlah informan ditentukan berdasarkan kecukupan data penelitian yang diperlukan.

\section{Kredibilitas Keturunan Alawiyyin dalam Proses Dakwah}

Keturunan Alawiyyin yang merupakan komunikator sekaligus etnis Asing yang berperan dalam menyampaikan pesan-pesan dakwahnya dan etnis Kaili yang mencampurcampurkan bahasa daerah dalam setiap interaksinya membuat keturunan Alawiyyin kesusahan dalam menyebarkan pesan-pesan agamanya. Menggunakan alat peraga dan bahasa Indonesia yang terbata-bata diambil sebagai jalan lain dari metode masuknya keturunan Alawiyyin di kota Palu. 
Kedatangan dalam membawa misi dan pesan agama ini tidaklah mungkin tanpa sebab. Kondisi sosial budaya yang digambarkan melalui pengamatan Gani Jumat dalam disertasinya bahwa kondisi itu benarbenar memprihatinkan dan ditambahkan oleh Abdullah A. Abdun sebelum berdirinya madrasah Alkhairaat, kota Palu hidup dalam kekacauan dan keguncangan (Jumat, 2012). Mereka tidak dipersatukan oleh suatu peraturan yang islami dan tidak dilindungi dari kesesatan oleh suatu hukum maupun undang-undang Islam. Hal ini kemudian yang menyarankan Habib Idrus untuk membuka dan membuka madrasah hingga akhirnya Habib Idrus juga memenuhi permintaan itu setelah melihatnya.

Para keturunan Alawiyyin sebagai komunikator tentunya telah menyadari bahwa mereka dilihat oleh khalayaknya lebih ke arah positif sebagai 'orang alim'. Orang alim merupakan dialek masyarakat etnis Kaili yang berarti seseorang yang sangat alim, rajin shalat, mengetahui halal dan haram, memberikan pesan- pesan sesuai syariat agama melalui media dakwah. Mochsen Ali Alhabsyi mengatakan bahwa Habib Idrus (Guru Tua) ini dianggap orangorang sebagai orang yang alim.

Habib Idrus selaku komunikator dalam menyampaikan misi dakwahnya benar-benar pada tahap menyampaikan apa yang menjadi awal dari kedatangan mereka di kota Palu tanpa memberikan kritik dengan apa yang sebenarnya dari awal sudah mereka lihat mengenai perilaku syirik etnis Kaili. Semata-mata yang mereka lakukan adalah untuk menghindari konflik pada awal pertemuan. Daya tarik Habib Idrus memang tidak bisa dipungkiri ketika ilmu agama yang dia bawa dari Hadramaut bisa disambut sebegitu hebatnya oleh etnis Kaili. Menurut pak Marzuki keturunan Arab hadramaut memang mengafiliasikan dirinya kekaum bangsawan terutama raja dan dapat diterima secara positif oleh raja dan rakyatnya sehingga mengurangi rasa ketidakpastian etnis Kaili.

Jika melihat dari awal, proses penerimaan pesan merupakan hal yang sangat mudah diterima oleh etnis Kaili. Pesan-pesan agama yang disampaikan oleh Habib Idrus begitu mudah untuk diterima etnis Kaili. Pengaruh Raja yang membawa Habib Idrus memasuki kota Palu tentulah diperhitungkan oleh rakyatnya.

Komunikator dalam hal ini para keturunan Alawiyyin tidak hanya berinteraksi dengan orang lain dan dengaan objek-objek sosial yang ada namun mereka berkomunikasi dengan diri mereka sendiri sebagai suatu bentuk proses interaksi. Proses ini kemudian diperlukan agar bisa membedakan hal yang dihadapi ini benda atau seorang manusia dan juga membantu Habib Idrus dan lainnya dalam mengambil suatu keputusan ataupun tindakan. Ini semua dapat dikatakan sebagi sebuah rencana tindakan yang dipandu oleh sebuah sikap atau pernyataan verbal yang dapat menunjukkan nilai-nilai agama terhadap tindakan yang akan diarahkan. Konsep diri ini tidak lebih dari sebuah rencana tindakan terhadap suatu identitas, citacita, ideologi ataupun paham, dan penilaian diri dari orang lain sehingga menurut Habib Ali, "Habib Idrus merupakan salah satu figur yang 
diterima oleh semua bahkan yang non muslim pun menerima". Habib Idrus adalah tokoh pembawa fajar baru, mengurangi kegelapan dan kebodohan ajaran-ajaran animisme dan bid'ah lainnya yang berada di Kota Palu.

\section{Konten Syiar-Syiar Islam Pada Daerah Terpencil}

Pendidikan merupakan salah satu aspek yang dapat membebaskan suatu kelompok dari kebodohan dan juga mencerdaskan kemudian membuka wawasan mereka kedepan. Pendekatan melalui pendidikan dan dakwah ini kemudian digunakan oleh keturunan Alawiyyin di Kota Palu yang dalam hal ini di pimpin oleh Habib Idrus Bin Salim Aljufri atau oleh etnis kaili senang memanggilnya dengan "Guru Tua". Guru tua bisa berkeliling ke daerahdaerah selama tiga bulan dan selalu membawa guru-guru yang sudah dianggap untuk bisa mengajarkan ilmu agama. Tatap muka selama tiga bulan yang dilakukan itu selalu membuahkan permintaan untuk juga membangun sekolah di daerah-daerah mereka.

Seperti dikatakan kebanyakan informan baik arab maupun kaili, Qira'ah merupakan cara keturunan Alawiyyin berhubungan dengan suku kaili. Qira'ah yang di lakukan dibawah rumah panggungnya bersifat seperti lingkaran kelompok ketika mereka ingin bertanya mengenai agama akan dijawab dan dijelaskan oleh Habib Idrus. Qira'ah yang hanya dilakukan pada waktu-waktu tertentu saja merupakan waktu untuk etnis Kaili bertanya apapun ke Guru Tua dan akan diberikan pandangan ke arah yang benar.
Perilaku Habib Idrus dalam melakukan Qira'ah, ceramah-ceramah agama secara tidak langsung mengurangi rasa ketidakpastian etnis Kaili dalam menerima pendatang. Hal tersebut merupakan kebutuhan dari etnis kaili untuk pendidikan agama yang belum tersedia di kota Palu. Menurut Dahlan Tangkaderi yang merupakan murid dan melihat proses penyebaran itu mengatakan bahwa ada penerjemah yang juga dipakai oleh Habib Idrus. Penerjemah dan alat peraga merupakan hal yang digunakan untuk menggapai etnis Kaili. Sadig yang juga mengakui alat peraga lebih mengatakan "Habib Idrus mengangkat sebuah barang lalu dia berkata bahasa Arabnya". Cara memakai alat peraga ini juga telah diilustrikan dalam sebuah film dokumenter yang mengisahkan Habib Idrus dan penerjemah juga digunakan Habib Idrus pada masa mengunjungi raja-raja untuk mempermudah proses komunikasinya. Alat peraga kemudian menjadi proses keturunan Alawiyyin memproduksi pesan mereka kepada etnis Kaili yang menjadi muridnya.

Alat peraga kemudian dapat diterima oleh etnis Kaili dan mereka dapat menelaah dengan cepat apa yang dimaksud oleh Habib Idrus pada saat mengangkat objek walaupun pada saat terjadi bentrokan bahasa antara Habib Idrus yang menggunakan bahasa Arab dan etnis Kaili menggunakan bahasa Kaili bercampur bahasa Indonesia dalam memahami objek peraga tersebut. Semua ini kemudian penulis simpulkan yang terlihat dalam ilustrasi yang mereka lakukan dalam film dokumenter. Adatadat yang dilihat oleh Habib Idrus tidak 
sesuai syariat agama namun tidak serta merta langsung diubah oleh para keturunan Alawiyyin ini. Habib Idrus tidak langsung mengubah namun diikuti. Semua kegiatan adat menurut Habib Ali akan diikuti oleh habib Idrus karena sifat rasa ingin tahu Habib Idrus sangatlah tinggi.

Qira'ah yang dimaksud ini adalah lebih kepada membaca kitab kemudian akan dijelaskan. Pada film yang dibuat oleh pengurus besar Alkhairaat, dalam film tersebut juga telah diilustrasikan proses Qira'ah tersebut banyak membuat etnis Kaili mengerti sedikit demi sedikit agama Islam itu sendiri melalui kitab. Seperti salah satu murid yang membaca ayat dalam kitab dan mendengarkannya di depan Habib Idrus "babul kalam, alkalam.." jika ada penyebutan yang salah menurut Habib Ali akan dibenarkan oleh Habib Idrus. Pengajaran yang dilakukan Habib Idrus dilakukan melalui media kitab dan hadist yang sesuai syariat agama.

Setiap hari Habib Idrus membimbing murid-muridnya Qira'ah kitab, menjawab ratusan pertanyaan baik dari para santri maupun masyarakat umum yang turut hadir di majelis halaqahnya. Bahkan sekalipun Habib Idrus duduk sendirian tetap dikelilingi oleh murid muridnya. Guru Tua membaca baik ketika sedang menuntun Qira'ah kitab kepada para santri maupun ketika duduk sendirian. Habib Idrus menghabiskan waktunya untuk membaca dan mengajar. (Jumat, 2012).

Dari semua informan keturunan Alawiyyin yang tidak lain merupakan ahli waris penerus pendidikan dan dakwah Habib Idrus mengatakan dalam proses penyebaran agama yang dilakukan Habib Idrus, bahasa Indonesia belum dikuasai oleh Habib Idrus, bahkan bisa dikatakan masih terbata-bata. Sangat membutuhkan usaha yang luar biasa dalam keseluruhan penyebaran yang menggunakan bahasa Arab sedangkan yang dihadapi ini merupakan putra putri daerah. Namun dengan kecerdasannya Habib Idrus kemudian memberikan pemahaman kepada masyarakat Kaili melalui alat peraga. Alat peraga merupakan kode non-verbal atau dalam arti lain yaitu artefak sebagai alat bantu yang terus menerus digunakan Habib Idrus dalam penyebaran ilmu dan agama islam. Dalam proses mengajarnya Habib Idrus menyebutkan bahasa Arab kemudian mengangkat alat peraga sehingganya anak-anak Kaili mampu memahaminya dan menjawab secara bahasa Indonesia. Dari sinilah kemudian terjadi proses saling bertukar pikiran untuk pelajaran bahasa bagi Habib Idrus dan etnis Kaili. Kendala bahasa mulai dapat teratasi ketika Habib Idrus terbantu oleh putra-putra daerah dalam menyebarkan syariat agama tersebut.

\section{Manifestasi Budaya Pendidikan Islam}

Walaupun beberapa etnis Kaili menyebutkan bahwa model bangunan souraja diadaptasi oleh bangunan sekolah Alkhairaat yang merupakan sekolah yang didirikan oleh Habib Idrus dan kini diteruskan oleh para anak dan cucu menjadi peninggalan bersejarah yang berdiri di Kota Palu kemudian menjadi milik bersama. Adanya Alkhairaat yang terbangun di Kota Palu sebagai lembaga pendidikan sekaligus dakwah pertama dikota Palu menajdikan Kota Palu menjadi pusat pemerintahan. 
Habib Idrus mempunyai niat dengan adanya Alkhairaat ini menurut Dahlan Tangkaderi, "siapa yang masuk di Alkhairaat akan mendapatkan kebaikan dunia wal akhirat sebagaimana kata Alkhairaat disebutkan sembilan kali dalam Al-Qur'an". Menurut M. Quraish Shihab dalam pidato Haul Guru Tua ke-41mengatakan bahwa kata Alkhairaat yang dipilih oleh Habib Idrus menyimbolkan visi misi dan khittah (garis perjuangan) untuk membimbing dan menyelamatkan umat islam bangsa Indonesia menuju jalan kebaikan dan kebenaran (Shihab, 2009).

Alkhairaat selain membuat kota Palu tersohor namanya namun juga dengan adanya Alkhairaat ini setidaknya dapat mengurangi paham animisme yang berada di Kota Palu. Walaupun adanya ritual-ritual yang masih dilakukan namun dakwah yang dilakukan Habib Idrus bisa diterima oleh etnis Kaili. Menurut M. Noor Sulaiman, masyarakat Sulawesi Tengah merupakan penganut agama yang fanatik. Namun dalam pemahaman agama Islam dan praktek dalam kehidupan keagamaan masih sangat terbatas sehingga dalam kehidupan sehari-hari masih terjadi percampuran dengan kepercayaan diluar Islam (Sulaiman, 1996).

Sejak dahulu sampai sekarang, apa yang dilakukan Alkhairaat dalam bidang pendidikan dan dakwah berjalan stabil dan tentunya membawa ketenangan dan ketentraman. Rum parampasi sendiri sebagi ketua adat Kaili mengakui sangat bersyukur dengan adanya Habib Idrus dan sekolahnya Alkhairaat. Itu tentunya sangat memberikan ketenangan bagi masyarakat Kaili dan menurutnya dimana-mana, agamalah yang menentukan.

Perspektif pendidikan agama yang ditawarkan oleh Habib Idrus kepada etnis Kaili kemudian menimbulkan kesetaraan dengan sikap saling menghormati antara keturunan Alawiyyin dan etnis Kaili di kota Palu dan juga saling tidak mendominasi diantara keduanya. Dibuktikan dengan tanpa adanya gesekan selama mereka hidup berdampingan dan ajakan demi ajakan dalam sebuah proses penyebaran agama yang tidak pernah ditolak oleh etnis Kaili dan juga penghormatan begitu luar biasa dilakukan etnis Kaili dikota Palu yang menganggap Habib Idrus sebagai guru dan juga keluarga-keluarga inti sebagai ahli waris.

Rasa berhutang budi etnis Kaili membuat dukungan-dukungan seperti ucapan, moril maupun materil terus diberikan semampunya oleh masyarakat kota Palu. Alkhairaat yang kini telah besar namanya dan tersebar di Indonesia Timur. Dukungan untuk sekolah-sekolah Alkhairaat tersebut, pesantren putraputri, TK, SD, SMP, Sanawiyah, SMA, Aliyah, sampai Universitasnya. Negosiasi komunikasi ataupun transaksional yang diperlihatkan etnis Kaili merupakan suatu proses komunikasi yang membuat Habib Idrus memberikan ilmu ajaran pendidikan dan dakwahnya yang bisa diberikan etnis Kaili adalah sebidang tanah yang dijadikan sekolah dan pondok pesantren Alkhairaat bisa berkembang semakin besar pada saat ini.

Madrasah Alkhairaat yang didirikan oleh guru tua mencakup kawasan timur (Kalimantan, sulawesi, maluku, maluku utara dan papua). Azra 
menyatakan bahwa Guru Tua sebagai orang pertama yang memainkan peranan penting dan merupakan pendidikan Hadramaut paling terkemuka di Indonesia. Sangatlah argumentatif apabila dilihat dari tolak ukur jaringan madrasah terluas khususnya dalam bidang pendidikan islam (Azra, 2008).

\section{Kesimpulan}

Kredibilitas komunikator untuk memberikan pesan-pesan agama kepada khalayak merupakan suatu komponen awal yang harus dimiliki oleh seorang komunikator. Latar belakang mufti dari Hadramaut membuat komunikator menambahkan poin lebih dalam menggapai umatnya. Proses komunikasi dalam pembentukan konten dakwah yang terjadi merupakan salah satu bentuk pendekatan evolusioner dan tidak melakukannya dengan cara radikal.

Efek kemudian yang didapatkan dari proses pendekatan yang dilakukan komunikator melalui metode ta'lim, tarbiyah, dan tahdzib tersebut dapat membawa pencerahan dalam kehidupan beragama. Hubungan keagamaan yang dibangun oleh keturunan Alawiyyin menyebabkan manifestasi budaya terwujud dalam bidang sekolah Alkhairaat, yayasan Alkhairaat dan juga peringatan kematian (Haul) Habib Idrus bin Salim Aljufri (Guru Tua) yang diperingati setiap tahun setelah hari raya Idul Fitri, persisnya 12 Syawal.

\section{Referensi}

Amin Wibowow. (2015). Strategi Komunikasi Dakwah (Strategi Komunikasi Dakwah Majelis
Dzikirdan Sholawat Jamuro

SURAKARTA). Surakarta :

Universitas Muhammadiyah

Surakarta.

A. Muri Yusuf. (2014). "Metode Penelitian Kuantitatif, Kualitatif dan Penelitian Gabungan. Prenadamedia Group.

Andi Markama. (2020). Komunikasi Dakwah Efektif Dalam Perspektif

Alquran. Hunafa : Jurnal Studia Islamika.

Arikunto, S. (2010). Prosedur Penelitian Suatu Pendekatan Praktik. Rineka Cipta.

Azra, A. (2008). Jaringan Ulama Timur Tengah dan Nusantara Abad XVII dan Xviii. Kencana.

Creswell, J. W. (2015). Penelitian Kualitatif dan Desain Riset (Ed Ke-3). Pustaka Pelajar.

Fitriani Yanti. (2019). Komunikasi Dakwah Dalam Kesenian Nasyid. Lampung : Institut Agama Islam Negeri Raden Intan Lampung. Vol 12.

Guntur Cahyono. (2019). Seni Komunikasi Dakwah Dan Media.. Jakarta: IAIN

Jumat, G. (2012). Nasionalisme Ulama Pemikiran Politik Kebangsaan Sayyid 'Idrus Bin Salim Aljufri' (1891-1969). Kementrian Agama Republik Indonesia. 
Kambay, S. B. (1991). Perguruan Islam Alkhairaat dari masa ke masa. T.P.

Konsultasi Syariah Islam Al-Khoirot. (2012). Pondok Pesantren AlKhairaat Palu Sulawesi Tengah. Konsultasi Syariah Islam AlKhoirot.

Mastura, H. R. (2015). Sambutan Walikota Palu Di Haul ke-47. PB Alkhairaat.

Ricklef, M. C. (2009). Sejarah Indonesia Modern 1200-2008. Serambi.

Rini Fitria. (2020). Urgensi Komunikasi Dakwah Di Era Revolusi Industri 4.0. Islamic Communication Journal.

Rozali, E. A. (2012). Sayid Muhammad Al-Sagoff In Johore- Ottoman Sovereign Relations. Advances in Natural and Applied Sciences, 6(6), 893-897.

Ruslan, H. (2017, March 24). Empat Golongan Utama Penduduk Hadramaut. Republika.Co.Id. https://republika.co.id/berita/duni a-islam/islamdigest/17/03/24/onatp7313empat-golongan-utamapenduduk-hadramaut

Shihab, Q. (2009). Pidato Haul ke-41. PB Alkhairaat.

Sulaiman, M. N. (1996). Peranan Alkhairaat Dalam Perubahan Sosial Budaya Masyarakat Kaili Di Sulawesi Tengah (19301996). IAIN Sunan Kalijaga.
Taufik Rahman. (2019). Komunikasi Dakwah Pesantren Tradisional Dalam Penyebaran Agama Islam. Jurnal Penelitian Sosial Keagamaan. Vol 9.

Yin. (2013). Studi Kasus Desain dan Metode. Grafindo Persada. 